\title{
Pioneer Evaluation of the Possible Side Effects of the Dna Insecticides on Wheat (Triticum Aestivum L.)
}

\author{
Oberemok Volodymyr, Nyadar Palmah", Zaytsev Oleksii, Levchenko Nataliya, \\ Shiyntum Honore, Omelchenko Olexandr
}

Department of Biochemistry, Taurida National V.I. Vernadsky University, 95007 Simferopol, Ukraine

*Corresponding Author:palmah_paul@yahoo.com

Copyright $(2013$ Horizon Research Publishing All rights reserved.

\begin{abstract}
The paper focuses on the pioneer evaluation of the possible side effects of a novel preparation against phyllophagous insects, DNA insecticides, on some biochemical parameters (concentration of glucose and activity of alkaline phosphatase) of wheat sprouts (Triticum aestivum L.). Our results show that the application of DNA insecticide based on single-stranded DNA fragment from RING domain of IAP-3 gene of gypsy moth multicapsid nuclear polyhedrosis virus results in significant difference in the decreased level of glucose and activity of alkaline phosphatase in wheat sprouts in comparison with the control after treatment on the second day of the experiment. However, the effect becomes significantly unnoticeable after one week when compared with the control. No significant difference in the dried biomass was found between wheat sprouts from the control and the experimental groups after the treatment on the seventh day and after three weeks on the Hoagland's substrate. Obtained results generally show that agricultural plants are able to overcome the misbalance in the concentration of glucose and activity of alkaline phosphatase caused by the DNA insecticides and emphasize good potential in harmlessness of DNA insecticides that could be used to control phyllophagous insects without substantial side effects on the crop.
\end{abstract}

Keywords DNA Insecticides, IAP-3 Gene of Ldmnpv, BIR and RING Domains, Tnsnpv, Ictvdb, Wheat, Alkaline Phosphatase, Glucose

\section{Introduction}

Increasing the efficiency of agricultural and forest defense against pest insects is vitally and economically very important. Baculoviruses have enormous potential in ecologically based microbiological control of the quantity of insect pests (Evans, Harrap 2004). The basic problem in the use of baculoviruses is the inability to accelerate the infection process and the death of the host substantially
(Vlak 1993; Moscardi 1999; van Beek and Davis 2007). A large field of research is devoted to improve baculoviruses by increasing the speed of their infection process through genetic modifications (Inceoglu et al. 2006). Biopreparations based on viral anti-apoptotic gene fragments, termed DNA insecticides, could be a safe, inexpensive and fast alternative to baculoviral preparations means of struggle against phyllophagous insects (Oberemok 2008; Oberemok 2009; Oberemok 2011; Simchuk et al. 2012; Oberemok et al. 2013). Viral genomes contain a genetic suite of anti-apoptotic genes, allowing them to highjack host metabolism (Bertin et al. 1996; Miller 1997). Many investigations suggest an eukaryotic cellular origin for the viral IAPs (inhibitor of apoptosis) (Hughes 2002). Relationships between baculoviruses and their insect hosts are subject to coevolution, this should lead to long-term evolutionary effects such as the specialization of these pathogens for their hosts (Herniou et al. 2004), and the ability to affect their biochemical reactions through expression of homologous anti-apoptotic genes. Thus, the fragments of anti-apoptotic genes have the potential to interfere with cellular biochemical reactions and eventually cause the cell death through the blocking of the mechanisms that manage post transcriptional expression of anti-apoptosis genes (Weiss et al. 1999; Lu et al. 2004; Ling and Ying 2001; Kawai-Toyooka et al. 2004; Fire et al. 1998). These mechanisms have a great perspective with respect to their application in agricultural environments, changing aim of pest control from pest elimination to pest control of its evolution towards decrease in its damaging capacity (Simchuk et al. 2012). In contrast to conventional insecticides that may harm vertebrates or kill arthropods indiscriminately, DNA insecticides have potential to target specific populations of insect pests since they possess great variability and specificity of sequences. This feature makes them compatible with classical biological controls in integrated pest management strategies (Enwistle et al. 1993) and they have potential to become useful for controlling insect pests in environmentally sensitive areas. While the idea of DNA insecticides may resemble the mechanisms that 
block post transcriptional expression of genes (Weiss et al. 1999; Lu et al. 2004; Ling, Ying 2001; Kawai-Toyooka et al. 2004; Fire et al. 1998), it has its own peculiar features such as its external application, small size of oligonucleotides, single-stranded DNA molecule and the concept of using viral anti-apoptosis genes. Our recent investigations show that specific single-stranded DNA fragments, 18 nucleotides long, representing parts of RING (really interesting new gene) and BIR (baculovirus IAP repeat) domains of the LdMNPV (Lymantria dispar multicapsid nuclear polyhedrosis virus) and TnSNPV (Trichoplusia ni single nuclear polyhedrosis virus) IAP-3 (inhibitor of apoptosis) gene significantly decrease the viability of gypsy moth caterpillars (Lymantria dispar (Lepidoptera: Erebidae)) (Oberemok 2008; Oberemok 2009; Oberemok 2011; Simchuk et al. 2012) and cabbage looper (Trichoplusia ni (Lepidoptera: Noctuidae)) (unpublished data). The DNA insecticides based on LdMNPV IAP-3 gene fragments can be selective in action, and at least are not harmful to tobacco hornworm (Manduca sexta (Lepidoptera: Sphingidae)) and black cutworm (Agrotis ipsilon, (Lepidoptera: Noctuidae)) (unpublished data).

One of the possible and convenient practical application ways of penetration of the DNA insecticides into the body of a caterpillar is an external one. It is known that the presence of developed epicuticule limits to some extent the permeability of a caterpillar's covers against most insecticides. Nevertheless, clororganical, organophosphate and other contact insecticides get through the epicuticule easily into the organism of an insect through the most permeable areas of the covers (Tyschenko 1986; Gu and Knipple 2013). Experiments on RNA interference have shown that negatively charged double-stranded RNA fragments are able to penetrate through the cuticle of the round worms (Maeda et al. 2001) and insects (Yu et al. 2013) which shows that despite the extra barriers, uptake of the dsRNA by whole insect bodies is possible (Yu et al. 2013, Pridgeon et al. 2008). The induction of RNAi by topical application of dsRNA could be explained by passage to interior tissues via the tracheal system (Gu and Knipple 2013). Single-stranded DNA molecules are more likely to penetrate into a cell because they have both hydrophilic (polar sugar-phosphate backbone) and hydrophobic (nitrogenous bases) parts that are thought to allow them penetrate through the polar and non-polar parts of insect tissues (Watson 1987).

In this regard, taking into account the external way of application of DNA insecticides, it is very important to prove specificity in action and harmlessness of DNA insecticides to main agricultural plants such as wheat (Triticum aestivum L.), to permit usage on a large scale. Wheat, a hexaploid species, is the most widely cultivated crop in the world. Many pest insects such as Hessian fly, wheat stem maggot, different armyworms and aphids, etc. damage part of the crop causing substantial and even massive loss of profit. A variety of pesticides and biological preparations are used to control the quantity of wheat pests (Petroczi et al. 2002;
Aktar et al. 2009; Rangwala et al. 2013).

Modern pesticides have different side effects on the wheat ranging from inhibition of the senescence of flag leaf with protracted chlorophyll retention (Petroczi et al. 2002) to harmful effect on the biochemical parameters of wheat seedlings (Rangwala et al. 2013). Also in many studies wheat grains were found to contain residues of pesticides harmful for the human health (Aktar et al. 2009). With the high rate of cultivation of wheat and use for food production, there is no doubt that there are health concerns associated with it, and so the need for alternative ways of crop management using safe preparations.

Pesticides can contaminate soil, water, turf, and other vegetation. In addition to killing insects or weeds, pesticides can be toxic to a host of other organisms including birds, fish, beneficial insects, non-target plants (Aktar et al. 2009) and human (Calvert et al. 2008). Insecticides are generally the most acutely toxic class of pesticides (Aktar et al. 2009). Thus, selectivity and safety of insecticides is the main characteristic that has to be checked in order not to disrupt the balance of an ecosystem. DNA insecticides have good potential to be harmless to the members of an ecosystem since deoxyribonucleic acid is the molecule found in every cell and with distinct sequences of nitrogenous bases we target natural mechanisms involved in expression of distinct genes in distinct organisms.

In this regard, the following research paper is devoted to the pioneer investigation of the influence of DNA insecticides on some biochemical parameters and biomass accumulation of seedlings of wheat, as the most vulnerable stage of the plant (Lianes et al. 2005), so as to evaluate the possible side effects of the DNA insecticides on the crop.

\section{Materials and Methods}

The seeds of wheat (Triticum aestivum L.) were collected from the Department of botany, plant physiology and biotechnology at Taurida National V.I. Vernadsky University (Simferopol, Ukraine). They were soaked for 16 hours in: 1) a solution of distilled water, 2) a solution containing fragments of BIR domain + distilled water, and 3) a solution containing fragments of RING domain + distilled water. The experimental BIR and RING groups (60 seeds each) were treated with $24 \mathrm{ml}$ of water solution containing fragments of BIR and RING domains respectively, at a concentration of $0.1 \mathrm{pmol} / \mu \mathrm{l}$. They were allowed to germinate on moist filter paper in Petri dishes (20 seeds per dish) at $24^{\circ} \mathrm{C}$ for 8 days. Part of the seedlings, after two days of germination, were transferred into vessels for cultivation (20 plants per vessel) containing Hoagland's substrate (fig. 1; fig. 2). The plants were grown at a constant air temperature of $23{ }^{\circ} \mathrm{C}$ under fluorescent light $10 \mathrm{klx}$ for three weeks, to evaluate the remote effect of DNA fragments on the biomass of the wheat seedlings. Safety measures were applied by use of spirit to sterilize the working area, in order to prevent contamination by environment. We designed DNA fragments according to the viral genome sequence (Kuzio et 
al. 1999) found in ICTVdb (International Commitee on Taxonomy of Viruses Database) (http://www.ictvonline.org) and synthesized them with the help of metabion international AG (Germany) with HPLC clearance. The sequences of the applied 2 single chain DNA fragments were the following: a) 5 ' -GCC GGC GGA ACT GGC CCA-3 ' (134843-134860; sense chain; BIR domain); b) 5' -CGA CGT GGT GGC ACG GCG-3 ' (135159-135142; antisense chain; RING domain). The dried biomasses of sprouts were weighed according to standard procedure, using a torsion scale BT-500 (Russia). Each sprout was grounded in $300 \mu \mathrm{l}$ of distilled water, and then $10 \mu \mathrm{l}$ of the extract was used to measure the concentrations of alkaline phosphatase and glucose with the help of kits manufactured by PZ CORMAY S.A. (Poland). Measurements of concentrations of glucose and alkaline phosphatase were performed with SINNOWA BS-3000m spectrophotometer (China). The experiment was performed in three replicates with twelve measurements per each variant. Statistical analysis was done using standard analytical tools (Microsoft Excel 7.0). The data corresponded to the conditions of application of the Student's test.

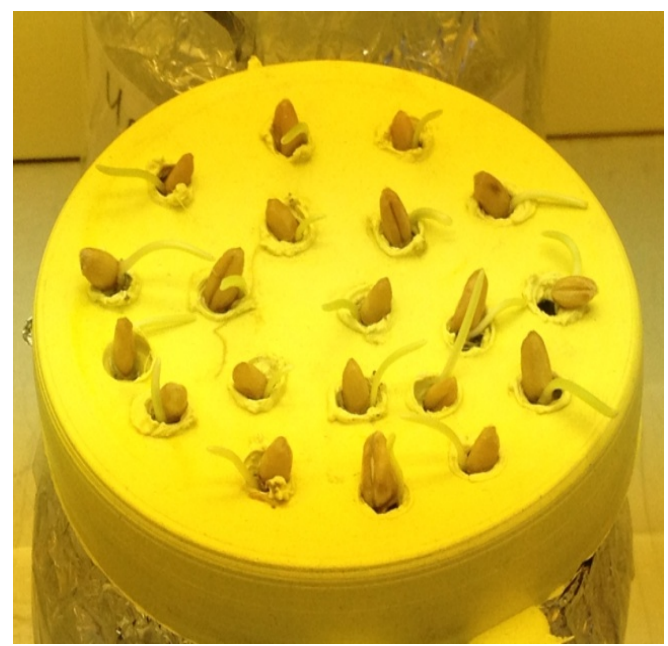

Figure 1. Sprouts of wheat on Hoagland's substrate during the experiment; two days after sprouting

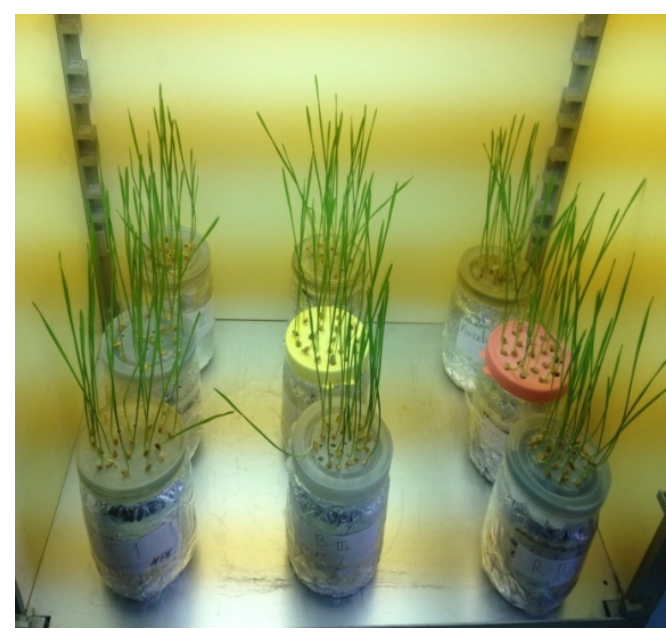

Figure 2. Sprouts of wheat on Hoagland's substrate during the experiment; three weeks after sprouting

\section{Results and Discussion}

The wheat sprouts responded differently to the administration of the different DNA fragments. Compared with the control significant decrease in the activity of alkaline phosphatase was observed for the trial group with RING fragment on the $2^{\text {nd }}$ day of the experiment whereas minor difference with the control group was found on the same day for the trial group with BIR fragment (fig. 3, table $1)$.

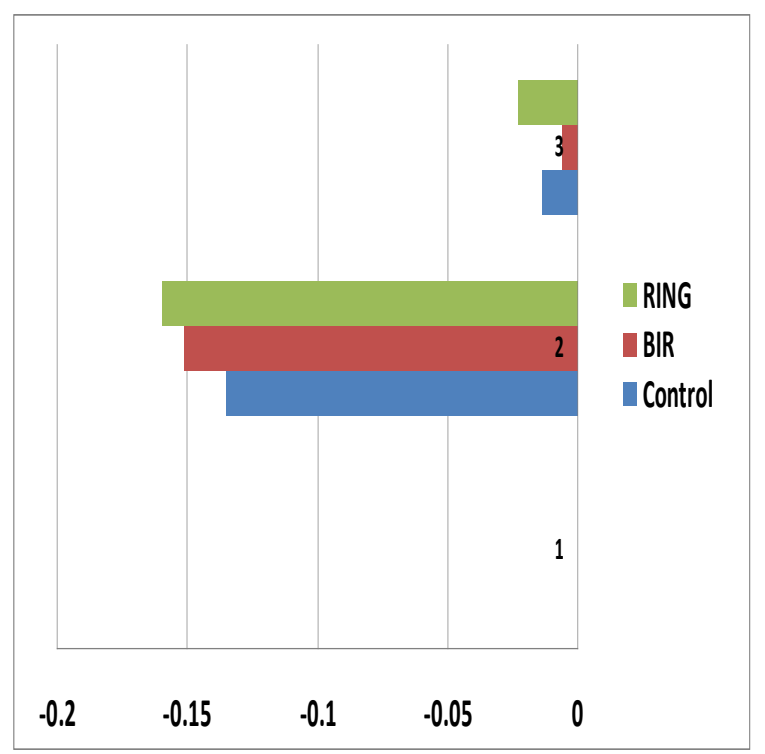

Figure 3. Differences in the concentration of alkaline phosphatase (U/1) in the control and trial groups: 1 - starting point, 2 - between the $1^{\text {st }}$ day and the $2^{\text {nd }}$ day of the experiment, 3 - between the $1^{\text {st }}$ day and the $7^{\text {th }}$ day of the experiment

No significant differences in the activity of alkaline phosphatase were observed on the $7^{\text {th }}$ day after comparing the concentration levels of the experimental groups (BIR and RING) with the control, finding out that the level of alkaline phosphatase was normalized in the RING trial group with respect to the control.

Similarly to the results obtained and represented on the fig. 3 and in the table 1 based on the alkaline phosphatase content, the effect of these fragments on the glucose content showed quite the same trend. Between the trial group with RING domain fragment and the control on the $2^{\text {nd }}$ day a significant difference in the concentration of glucose was found (fig. 4, table 1). No significant difference was detected after 7 days of the experiment between experimental groups (BIR and RING) and control.

Thus, statistically significant differences in comparison with the control were found in the experimental groups containing DNA fragment of the RING domain of LdMNPV IAP-3 gene with the test of alkaline phosphatase and glucose content on the $2^{\text {nd }}$ day but recovery was noted on the $7^{\text {th }}$ day. The obtained results generally imply on harmlessness of DNA insecticides based on the BIR and RING domain fragments on wheat sprouts. Taking into consideration that 
chemical pesticides generally have long-term side effects on non-target organisms (Aktar et al. 2009), DNA fragments used as DNA insecticides have good potential to be a safer preparation for the biochemical parameters of the wheat's cell.

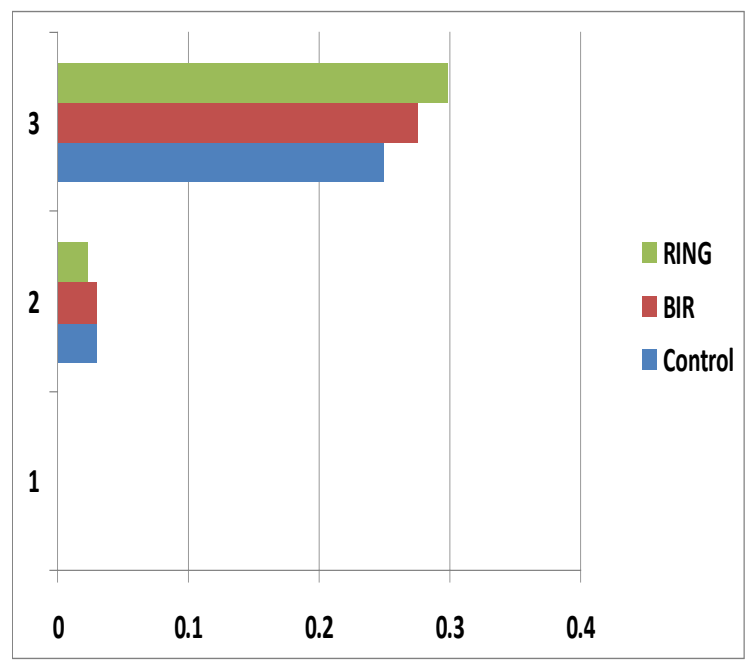

Figure 4. Differences in the concentration of glucose (mg/dl) in the control and trial groups: 1 - starting point, 2 - between the $1^{\text {st }}$ day and the $2^{\text {nd }}$ day of the experiment, 3 - between the $1^{\text {st }}$ day and the $7^{\text {th }}$ day of the experiment

Table 1. The P-values found by Student's test for the different points of the experiment

\begin{tabular}{|c|c|c|}
\hline \multicolumn{3}{|c|}{ Start $-2^{\text {nd }}$ day } \\
\hline \multicolumn{3}{|c|}{ Alkaline phosphatase } \\
\hline Control/RING & Control/BIR & $\mathrm{BIR} / \mathrm{RING}$ \\
\hline $0.039 *$ & 0.105 & 0.224 \\
\hline \multicolumn{3}{|c|}{ Glucose } \\
\hline Control/RING & Control/BIR & BIR/RING \\
\hline $0.035^{* *}$ & 0.483 & $0.047^{*}$ \\
\hline \multicolumn{3}{|c|}{$2^{\text {nd }}$ day $-7^{\text {th }}$ day } \\
\hline \multicolumn{3}{|c|}{ Alkaline phosphatase } \\
\hline Control/RING & Control/BIR & $\mathrm{BIR} / \mathrm{RING}$ \\
\hline 0.252 & 0.318 & 0.491 \\
\hline \multicolumn{3}{|c|}{ Glucose } \\
\hline Control/RING & Control/BIR & $\mathrm{BIR} / \mathrm{RING}$ \\
\hline 0.0534 & 0.293 & 0.071 \\
\hline \multicolumn{3}{|c|}{ Start $-7^{\text {th }}$ day } \\
\hline \multicolumn{3}{|c|}{ Alkaline phosphatase } \\
\hline Control/RING & Control/BIR & $\mathrm{BIR} / \mathrm{RING}$ \\
\hline 0.433 & 0.460 & 0.407 \\
\hline \multicolumn{3}{|c|}{ Glucose } \\
\hline Control/RING & Control/BIR & $\mathrm{BIR} / \mathrm{RING}$ \\
\hline 0.099 & 0.293 & 0.15 \\
\hline
\end{tabular}

*1-tailed test; **2-tailed test; P-values were obtained with 1-tailed test (except pair Control/RING for glucose between start\&2 $2^{\text {nd }}$ day of the experiment)
According to previous researches, alkaline phosphatase is a hydrolase enzyme responsible for removing phosphate groups from many types of molecules, including nucleotides, proteins, and alkaloids and is the most effective in an alkaline environment (Trowsdale et al., 1990; Holtz and Kantrowitz, 1999). Alkaline phosphatase is used in human physiology as a diagnostic tool for finding health problems. Elevated as well as decreased levels of alkaline phosphatase serve as markers of some pathological processes in human organism (Lange et al. 1982; Remaley and Wilding 1989). The use of level of alkaline phosphatase for plants may be helpful as a marker of a cell's general condition because the reaction of releasing of inorganic phosphate is very frequent and ubiquitous (Tamás et al. 2002). In plants, alkaline phosphatase activity in seeds often increases greatly during germination, indicating a possible role in phosphate metabolism and mobilization (Duff and Sarath 1994). Also the production of plant hydrolases such as alkaline phosphatase might be one of the components of the complex mechanism of polysaccharide-induced plant protection responses (Tamás et al. 2002). Since we detected decreased level of alkaline phosphatase for the trial group with RING fragment on the $2^{\text {nd }}$ day of the experiment, it indicates that this oligonucleotide worsened the condition of wheat cells. The mechanism of how it happens needs further investigation to find an answer to avoid even the slightest chance to harm the plant.

According to Dekkers et al. (2004), glucose plays roles such as energy supply, metabolism, development, cell proliferation, and cell death in plants and other organisms. The seed germination due to photosynthesis and cell growth is directly proportional to the change in glucose levels. The second day of our experiment rendered results with a gradual increase in the glucose content, with a significant difference between the control and experimental RING group. It indicates that fragment of the RING domain of LdMNPV IAP-3 gene for a short period of time interfered with the normal accumulation of glucose in the cell. The RING domain fragment could negatively act on the wheat cells through the blocking of the mechanisms that manage post transcriptional expression of genes (Weiss et al. 1999; Lu et al. 2004; Ling and Ying 2001; Kawai-Toyooka et al. 2004; Fire et al. 1998) involved in photosynthesis. We cannot also ignore the fact that DNA is able to interact with a large number of proteins and thus, can affect their functional activity (Cai and Huang 2012). The mechanism of this phenomenon needs further investigation.

The masses obtained from weighing the dried roots and stems of 47 seedlings per medium (in three replicates) after 7 days of the experiment provided non-significant results between the control and experimental groups (fig. 5). Thus, the DNA fragments had no real effects on the biomass of the seedlings.

We also did not notice any significant negative effect of DNA insecticides evaluating dry masses of wheat sprouts bred on the Hoagland's substrate during three weeks (fig. 6). Surprisingly, trial groups showed a little bit higher average 
indexes in comparison with the control. This serves as a further confirmation that there were no significant biomass losses registered by the weed seedlings after the application of the BIR and RING domain fragments. Thus, this is the evidence that there are no long-term side effects of DNA insecticides on the biomass of wheat sprouts.

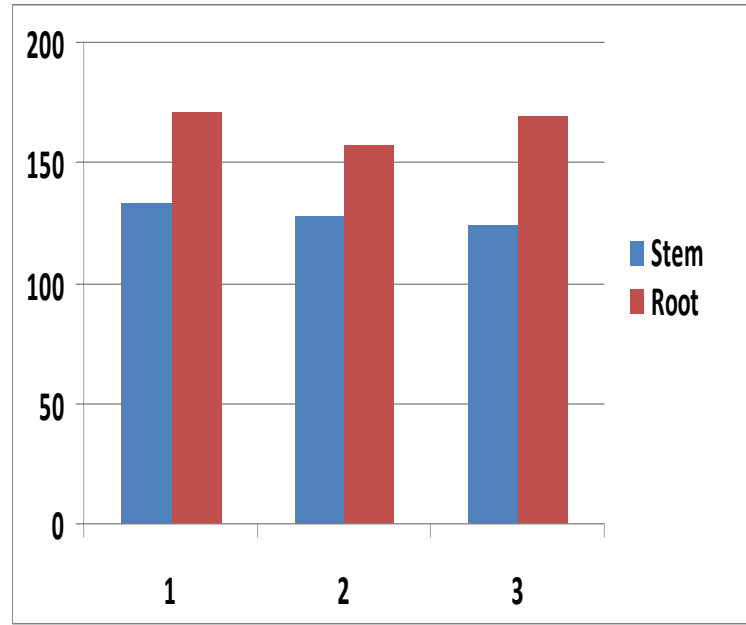

Figure 5. The average values of dried biomass (in mg per 47 seedlings) after 7 days of the experiment in the control (1) and trial groups BIR (2) and RING (3)

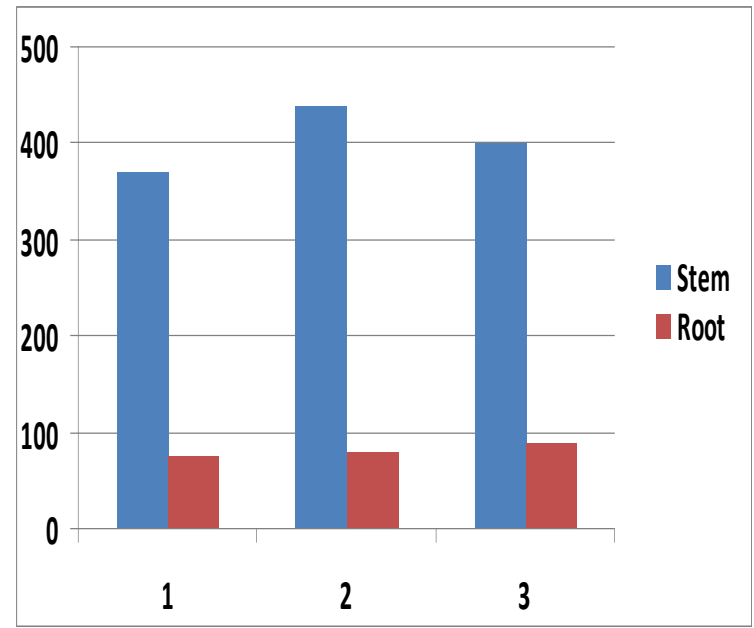

Figure 6. The average values of dried biomass (in mg per 20 seedlings) after three weeks of the experiment in the control (1) and trial groups BIR (2) and RING (3) bred on Hoagland's substrate.

\section{Conclusion}

The world is craving for a higher yield in crop production and seeks for a better solution to eliminate pest insects without damaging agricultural plants, other beneficiary insects, and the environment. Regulation of pest quantity requires a safe, an effective and a cheap method. A possible way to improve modern insecticides is the development of a new preparation, DNA insecticides, which will manifest the sum of their best characteristics: fastness and cheapness of chemical pesticides and safety from baculoviral preparations. Having already proven in previous publications that DNA insecticides could prove to be effective insecticides (Oberemok 2008; Oberemok 2009; Obermok 2011; Simchuk et al, 2012; Oberemok et al. 2013), this new paper provides more accuracy as to their safety.

Obtained results generally show that agricultural plants are able to overcome the misbalance in the concentration of glucose and activity of alkaline phosphatase caused by the DNA insecticides. Also no significant difference in the dried biomass was found between wheat sprouts from the control and the experimental groups after the treatment on the seventh day of the experiment and after three weeks on the Hoagland's substrate. This indicates the harmlessness of DNA insecticides that could be used to control phyllophagous insects without substantial side effects on the crop.

Thus, our pioneer evaluation of the possible side effects of a novel preparation against phyllophagous insects, DNA insecticides, on some biochemical parameters (concentration of glucose and activity of alkaline phosphatase) and biomass of wheat sprouts has not found serious negative effect on the plant.

\section{Acknowledgement}

We are grateful for the kind assistance by the laboratory experts (Biochemistry Department, Taurida National V.I. Verdnadsky University) and for their valuable contributions.

\section{REFERENCES}

[1] Aktar MW, Sengupt D, Chowdhury A, 2009. Impact of pesticides use in agriculture: their benefits and hazards. Interdisc Toxicol. 2(1):1-12.

[2] Van Beek N, Davis DC, 2007. Baculovirus insecticide production in insect larvae. In: Murhammer DW (Ed.), Methods in Molecular Biology. 2nd edition. Baculovirus and Insect Cell Expression Protocols, vol. 38. Humana Press, Totowa, NJ, pp. 367-370.

[3] Bertin J, Mendrysa SM, LaCount DJ, Gaur S, Krebs JF, Armstrong RC, Tomaselli KJ, Friesen PD, 1996. Apoptotic suppression by baculovirus P35 involves cleavage by an inhibition of a virus induced CED - 3/ICE-like protease. J. Virol. 70:6251-6259.

[4] Cai YH, Huang H, 2012. Advances in the study of protein-DNA interaction. Amino Acids 43 (3):1141-6. doi:10.1007/s00726-012-1377-9.

[5] Calvert GM, Karnik J, Mehler L, Beckman J, Morrissey B, Sievert J, Barrett R, Lackovic M, Mabee L, Schwartz A, Mitchell Moraga-Mchaley, 2008. Acute pesticide poisoning among agricultural workers in the United States, 1998-2005. American Journal of Industrial Medicine 51(12):883-898. doi:10.1002/ajim.2062 
[6] Duff SMG, Sarath G, Plaxton WC, 1994. The role of phosphatase in plant phosphorus metabolism. Physiologia Plantarum. No.90:791 - 800

[7] Dekkers BJW, Schuurmans JAMJ, Smmeekens SCM, 2004. Planta. 218:579-588.

[8] Entwistle PF, Cory JS, Bailey MJ, Higgs S, 1993. (Eds): Bacillus thuringiensis, An Environmental Biopesticide: Theory and Practice. Chichester: John Wiley \& Sons.

[9] Evans HF, Harrap K A, 1982. Persistence of insect viruses. In: Minson A. C., Darby G. K. (Eds) Virus Persistence. SGM Symposium. Cambridge, Cambridge University Press. pp. 57-96.

[10] Fire A, Xu S, Montgomery M, Kostas S, Driver S, Mello C, 1998. Potent and specific genetic interference by double-stranded RNA in Caenorhabditis elegans. Nature. 391 (6669):806-11.

[11] Gu L, Knipple DC, 2013. Recent advances in RNA interference research in insects: Implications for future insect pest management strategies. Crop Prot. 45:36-40.

[12] Hammock BD, Bonning BC, Possee RD, Hanzlik TN, Maeda S, 1990: Expression and effects of the juvenile hormone esterase in a baculovirus vector. Nature. 344:458-461.

[13] Herniou EA, Olszewski JA, O'Reilly DR, Cory JS, 2004. Ancient coevolution of baculoviruses and their insect hosts. J Virol 78:3244-3251.

[14] Holtz KM, Kantrowitz ER, 1999. The mechanism of the alkaline phosphatase reaction: insights from NMR, crystallography and site-specific mutagenesis. FEBS Lett. 462:7-11.

[15] Hughes AL, 2002. Evolution of inhibitors of apoptosis in baculoviruses and their insect hosts. Infect Genet Evol 2:3-10.

[16] Inceoglu AB, Kamita SG, Hammock BD, 2006. Genetically modified baculoviruses: a historical overview and future outlook. Adv in Virus Res 68: 323-360

[17] Kawai-Tayooka H, Kuramoto C, Orui K, Motoyama K, Kikuchi K, Kanegae T, Wada M, 2004. DNA interference: a simple and efficient gene-silencing system for high-throuput functional analysis in the fern Adiantum. Plant Cell Physiol 45:1648-1657.

[18] Kuzio J, Pearson MN, Harwood SH, Funk CJ, Evans JT, Slavicek J, Rohrmann GF, 1999. Sequence and analysis of the genome of a baculovirus pathogenic for Lymantra dispar. Virology. 253:17-34

[19] Lange PH, Millan JL, Stigbrand T, Vessella RL, Ruoslahti E, Fishman WH, August 1982. "Placental alkaline phosphatase as a tumor marker for seminoma". Cancer Res. 42 (8): $3244-7$.

[20] Lianes A, Reinoso H, Luna V, 2005. Germination and Early Growth of Prosopis strombulifera Seedlings in Different Saline Solutions. World J. Agric Sci. 1(2):120-128.

[21] Lin S-L, Ying S-Y, 2001. D-RNAi is a novel defense system against cancers and viral infections. Current Cancer Drug Targets. 1: 241-247.

[22] Lu X, Yu Q, Binder GK, Chen Z, Slepushkina T, Rossi J,
Dropulic B, 2004. Antisense-mediated inhibition of human immunodeficiency virus (HIV) replication by use of an HIV type 1-based vector results in severely attenuated mutants incapable of developing resistance $\mathrm{J}$ of Virol. 78 (13):7079-88.

[23] Maeda S, 1989. Increased insecticidal effect by a recombinant baculovirus carrying a synthetic diuretic hormone gene. Biochem Biophys Res Commun. 165:1177-1183.

[24] Maeda I, Kohara Y, Yamamoto M, Sugimoto A, 2001. Large scale analysis of gene function in Caenorhabditis elegans by high throughput RNAi. Curr. Biol. 11:171-176.

[25] Miller L K, 1997. Baculovirus interaction with host apoptotic pathways. J. Cell. Physiol. 173:178-182.

[26] Moscardi F, 1999. Assessment of the application of baculoviruses for control of Lepidoptera. Ann Rev Entomol 44:257-289.

[27] Oberemok VV, 2008 Method of elimination of phyllophagous insects from order Lepidoptera, Patent of Ukraine. №36445.

[28] Oberemok VV, 2009. Influence of a single chain DNA fragments of virus IAP gene LdnVgp140 on viability of Lymantria dispar caterpillars. Ukr Biochem J 8 (4):171.

[29] Oberemok VV, 2011. DNA markers in investigation of interaction between Lymantria dispar multicapsid Nucleopolyhedrovirus and its host gypsy moth, Published $\mathrm{PhD}$ thesis, Taurida National VI Vernadsky University, Simferopol.

[30] Oberemok VV, Simchuk AP, Gninenko Yu.I, 2013. DNA insecticides: application of the iap-2 gene single-stranded fragments from three different nucleopolyhedroviruses against second instar gypsy moth larvae. Universal Journal of Applied Science. 1 (2):33-37.

[31] O'Reilly DR, Miller LK, 1989. A baculovirus blocks insect molting by producing ecdysteroid UDP-glucosyl transferase. Science. 245:1110-1112.

[32] Petróczi I M, Matuz J, Kótai C, 2002. Study of pesticide side-effects in winter wheat trials. Acta Bio. Szeged. 46(3-4):207-208.

[33] Pridgeon JW, Zhao L, Becnel JJ, Strickman DA, Clark GG, Linthicum KJ, 2008. Topically applied AaeIAP1 double-stranded RNA kills female adults of Aedes aegypti J. Med. Entomol. 45:414-420.

[34] Rangwala T, Bafna A, Maheshwari R S, 2013. Harmful effects of fungicide treatment on wheat (Triticum aestivum L.) seedlings Int. Res. J. Environment Sci. 2(8):1-5.

[35] Remaley AT, Wilding P, 1989. Macroenzymes: biochemical characterization, clinical significance and laboratory detection. Clinical Chemistry. No.35: 2261-2270

[36] Simchuk AP, Oberemok VV, Ivashov AV, 2012. Genetics of interactions among moths, their host plants and enemies in Crimean oak forests, and its perspective for their control.

[37] Stewart LMD, Hirst M, Ferber ML, Merryweather AT, Cayley PJ, Possee RD, 1991. Construction of an improved baculovirus insecticide containing an insect-specific toxin gene. Nature. 352:85-88.

[38] Tabara H, Grishok A, Mello CC, 1998. RNAi in C. elegans: 
soaking in the genome sequence. Science 282:430-431

[39] Tamás L, Huttová J, Mistrk I, Kogan G, 2002. "Effect of Carboxymethyl Chitin-Glucan on the Activity of Some Hydrolytic Enzymes in Maize Plants". Chem. Pap. 56 (5):326-329.

[40] Tomalski MD, Miller LK, 1991. Insect paralysis by baculovirus mediated expression of a mite neurotoxin gene. Nature. 352:82-85.

[41] Trowsdale, J., D. Martin, D. Bicknell and I. Campbell, 1990. Alkaline phosphatases. Biochem. Soc. Trans. 18: 178-180.

[42] Tyschenko V P, 1986. Phiziologiya nasekomyh. Vyssh. Shk, Moscow.
[43] Vlak JM, 1993. Genetic engineering of baculoviruses for insect control. In: Oakeshott J, Whitten MJ (eds) Molecular Approaches to Fundamental and Applied Entomology. Springer, New York.

[44] Watson JD, 1987. Molecular Biology of Gene. W. A. Benjamin, New York.

[45] Weiss B, Davidkova G, Zhou L-W1, 1999. Antisense RNA gene therapy for studying and modulating biological processes. Cell. Mol. Life Sci. 55:334-358.

[46] Yu N, Christiaens O, Liu J, Niu J, Cappelle K, Caccia S, Huvenne H, Smagghe G, 2013. Delivery of dsRNA for RNAi in insects: an overview and future directions. Insect Science. 20:4-14. 